\title{
KINETICS AND MECHANISM OF ANODIC OXIDATION OF NITRITE ION IN NITRATE MELTS ON PLATINUM ELECTRODES*
}

\author{
M. E. Martins, A. J. Calandra and A. J. Arvía \\ Instituto Superior de Investigaciones, Facultad de Ciencias Exactas, \\ Universidad Nacional de La Plata, La Plata, Argentina.
}

\begin{abstract}
The electrochemical oxidation of nitrite ion in $\mathrm{KNO}_{3}-\mathrm{NaNO}_{3}$ eutectic melt on a platinum rotating disk electrode has been studied in the temperature range 247 to $312^{\circ} \mathrm{C}$.

The current/voltage curves comprise at least two regions. At high overvoltages the process is under a net convective diffusion control whereas at low ones the kinetics of the electrode process involves both convective diffusion and activation-polarization terms. From the current/voltage curves the kinetic parameters of each contribution are evaluated as well as the diffusion coefficient of nitrite ion in the melt.

The electrode process is discussed in terms of the over-all reaction $\mathrm{NO}_{2}{ }^{-} \rightarrow \mathrm{NO}_{2}+\mathrm{e}$ and of the reaction mechanisms previously postulated, where the initial electron-transfer step becomes ratedetermining as the nitrite ion concentration diminishes. The results are compared to those obtained with the pure nitrite melt.
\end{abstract}

Résumé - On a étudié l'oxidation électrochimique de l'ion nitrite dilué dans le mélange eutectique $\mathrm{KNO}_{3}-\mathrm{NaNO}_{3}$ sur une électrode a disque tournant de platine, a des températures comprises entre 247 et $312^{\circ} \mathrm{C}$.

Les courbes de polarisation montrent au moins deux régions. A de hautes surtensions le procès est déterminé par une diffusion convective, tandis que à de basses surtensions la cinétique du procès d'électrode comprend des contributions simultanées de la diffusion convective et de la polarisation d'activation. On a evalué les paramètres cinétiques de chaque contribution et également le coefficient de diffusion de l'ion nitrite dans le mélange moyennant les courbes de polarisation.

On discute le procès d'électrode sur la base de la réaction total $\mathrm{NO}_{2}-\rightarrow \mathrm{NO}_{2}+e$, et des méchanismes de réaction presentés antérieurement, où l'étape initial qui est la transférence d'un électron, devient l'étape régulatrice quand la concentration de l'ion nitrite diminue. Les données expérimentales sont comparées avec celles obtenues pour le nitrite pur fondu.

Zusammenfassung-Es wurde die elektrochemische Oxidation von Nitrition in geschmolzener Nitratenmischung ( $\left.\mathrm{KNO}_{3}-\mathrm{NaNO}_{3}\right)$ mittels einer Drehscheibenelektrode aus Platin, im Temperatur bereich von 247 bis $312^{\circ} \mathrm{C}$ untersucht.

Die Strom-Spannungskurven umfassen wenigstens zwei verschiedene Gebiete. Bei höheren Überspannungen verläuft der Vorgang unter reinem konvektivem Diffusionskontroll und bei kleineren hat man einen gemischten Kontroll indem der Aktivierungsprozess eine wichtige Rolle spielt. Aus den Strom-Spannungskurven wurden die kinetischen Parameter, sowie der Diffusionskoeffizient vom Nitrition in der Schmelze bestimmt.

Der Elektrodevorgang wird diskutiert auf Grund der Gesamtreaktion $\mathrm{NO}_{2}{ }^{-} \rightarrow \mathrm{NO}_{2}+\mathrm{e}$, und der fruher vorgeschlagenen Mechanismen, in dem die anfangliche Elektronsdurchtrittreaktion bei abnehmender Nitritkonzentration Geschwindigkeitsbestimmend wird. Die vorliegenden Erbegnissen werden mit den Resultaten für reine Nitritechmelze verglichen.

\section{INTRODUCTION}

EARLIER electrochemical studies of solutions of alkali nitrites in nitrate melts were mainly orientated towards analytical applications. Thus, it was found that the total reaction on a platinum anode was related to a diffusional wave corresponding to a one-electron process, the limiting current being proportional to the nitrite ion concentration. ${ }^{1-3}$ More recently it was reported that the couple $\mathrm{NO}_{2} / \mathrm{NO}_{2}^{-}$on platinum

* Manuscript received 22 July 1968. 
can be studied in both anodic and cathodic directions, the latter corresoponding to the electrochemical reduction of nitrogen dioxide. ${ }^{4}$

Kinetic studies of the anodic oxidation of nitrite ion from pure nitrite melts both on platinum and graphite electrodes showed that within a rather large cd range these processes are activated. ${ }^{5-6}$ The reaction mechanisms involve the participation of at least one intermediate species $\left(\mathrm{NO}_{2}\right)$ adsorbed on the electrode surface. The electrode kinetics was explained without involving the nitronium ion $\left(\mathrm{NO}_{2}{ }^{+}\right)$as a reaction intermediate. This has been postulated in the thermal decomposition of molten nitrites and nitrates and in other chemical reactions of donor-acceptor type involving molten nitrates and nitrites. ${ }^{7-15}$

The participation of nitronium ion in the kinetics of the anodic oxidation of nitrite has been ruled out in a recent chronopotentiometric investigation of the reaction on oxidized platinum electrodes. ${ }^{10}$ These results are, furthermore, coincident with reactions involved in the thermal decomposition of nitrites, such as the following oxidation of nitrite occurring in the presence of nitrogen dioxide,

$$
\mathrm{NO}_{2}^{-}+\mathrm{NO}_{2} \rightarrow \mathrm{NO}_{3}^{-}+\mathrm{NO},
$$

which is a fast reaction. ${ }^{17-19}$ A further confirmation of the acid behaviour of $\mathrm{NO}_{2}$ as in reaction (1) was obtained by studying acid-base equilibria in molten nitrates, yielding additional support to eliminate not only nitronium-ion participation but also that of nitrosonium ion.

The literature on the subject is scarce and contradictory. For the over-all reaction involved in nitrite ion anodic oxidation in the melt, several authors refer to nitrogendioxide formation as the main process, whereas others indicate (1) as prevailing, particularly for pure melts. Another point of discrepancy is the electrochemical activity of nitrogen dioxide. Earlier work ${ }^{3}$ could not detect any activity of the gas, but the most recent papers confirm the actual existence of the $\mathrm{NO}_{2} / \mathrm{NO}_{2}^{-}$couple on platinum. Once this question was settled a new disagreement arose concerning the nitrite concentration range where the $\mathrm{NO}_{2} / \mathrm{NO}_{2}^{-}$couple was actually stable. Thus, some authors indicate that as reaction (1) is a fast process, the $\mathrm{NO}_{2} / \mathrm{NO}_{2}{ }^{-}$ couple is stable only in dilute nitrite solutions in molten alkali-nitrate melts. On the other hand, we have obtained a reversible potential assigned to a nitrite electrode with a pure molten sodium nitrite. ${ }^{20}$

Many problems must be solved in order to gain a sounder knowledge of the electrochemical behaviour of nitrite and nitrate melts. One of them is the kinetic study of dilute nitrite solutions on platinum electrodes. The electrochemical reaction will easily cover a region of potential where a large convective-diffusion contribution to overvoltage must occur; therefore, in order to establish the parameters of the electrode reaction, it has been studied with a rotating disk electrode, which is satisfactory for problems of intermediate kinetics.

\section{EXPERIMENTAL TECHNIQUE}

Electrolysis cell

An air-tight electrolysis cell was made of Pyrex glass tubing of $8 \mathrm{~cm}$ diameter. It consisted of an upper part with five holes for the electrodes and gas inlets and outlets and a rounded bottom second part that contained about $600 \mathrm{~cm}^{3}$ of molten electrolyte. Three electrodes were employed in each run: a platinum rotating disk 
working electrode, described further on, a platinum wire counter-electrode of large surface area, lodged in a separated section of the cell ending with a sintered glass disk, and a $\mathrm{Ag} / \mathrm{Ag}^{+}$reference electrode, also placed in a separated section with a LugginHaber capillary tip. The silver wire was dipped in the nitrate solvent containing $0.1 \mathrm{M}$ silver nitrate. The reversibility of the $\mathrm{Ag} / \mathrm{Ag}^{+}$electrode in the molten nitrates is well known.

The rotating disk electrode was specially designed to operate in melts. The disk was mounted at the end of a stainless steel shaft of $25 \mathrm{~cm}$ long and $1.2 \mathrm{~cm}$ diameter. The shaft was centred and kept in position by means of a set of stainless steel shielded bearings refrigerated with water circulation. The electrical contacts operated by means of a cylindrical copper piece attached to the upper part of the rotating shaft and carbon rods symmetrically placed around the copper piece. The shaft was mechanically coupled to the driven motor with hard rubber. The motor and control device to run the rotating disk electrode are described elsewhere. ${ }^{21}$

The working electrode itself was a platinum cylinder embedded in one end of a Pyrex glass tubing so as to obtain, after polishing, a flat glass disk of $14 \mathrm{~mm}$ diameter concentrically with a platinum disk of $3 \mathrm{~mm}$ diameter. The electrode was screwed to the rotating shaft by means of a Sindanyo rod fixed inside the glass tubing. Electrical contact was made in the usual way.

The electrolysis cell was installed into an air thermostat, the temperature of the system being controlled both inside and outside of the cell by means of $\mathrm{Ni}-\mathrm{Cr} / \mathrm{Ni}-\mathrm{Al}$ shielded thermocouples.

The operating conditions of the rotating disk electrode arrangement was tested by electrolysing a known aqueous system (potassium ferro- and ferricyanide in $\mathrm{KOH}$ ) at room temperature ${ }^{21}$ and evaluating the diffusion coefficients of these ions.

\section{Preparation of the electrolyte}

The electrolyte consisted of sodium nitrite in an eutectic mixture of sodium and potassium nitrates. Analytical reagents were employed after moisture elimination. The ground mixture of salts was first dried at $120^{\circ} \mathrm{C}$ for 3 days and later molten under vacuum for about $3 \mathrm{~h}$ before pouring it into the electrolysis cell, which already was in the thermostat at the temperature of the run. Afterwards the electrolyte was saturated with purified nitrogen.

The same procedure was also followed with the $0.1 \mathrm{M}$ silver nitrate dissolved in the eutectic, which was contained in the reference-electrode section.

\section{Electrical measurements}

Current/voltage curves were determined with circuitry already described in previous publications. To obtain each current/voltage curve the rotating disk electrode was polished to a mirror surface. During the recording of a current/voltage curve nitrogen was not bubbled through the bulk of the melt but the gas was kept streaming on the electrolyte surface. Current/voltage curves were recorded both in the direction of increasing as well as decreasing cd. Usually successive runs were performed by increasing or decreasing the speed of rotation of the working electrode.

The pseudo-ohmic drop between the working electrode and reference electrode was determined by the interrupter method as described elsewhere. 


\section{Measurement of viscosity}

The viscosity of the electrolyte was measured with a capillary viscometer suitable for melts made of Pyrex glass which is described in the literature. ${ }^{22}$ The viscometer operated under nitrogen and the electrolyte levels were determined by means of electrical contacts acting upon an electronic timer.

\section{RESULTS AND INTERPRETATION}

\section{Current/voltage curves}

Current/voltage curves were determined in nitrite ion concentrations ranging from $1.3 \times 10^{-3}$ to $17.5 \times 10^{-3} \mathrm{M}$, at temperatures between 247 and $312^{\circ} \mathrm{C}$ and rotation speed of the working electrode from 166 to $1645 \mathrm{rev} / \mathrm{min}$. In addition to

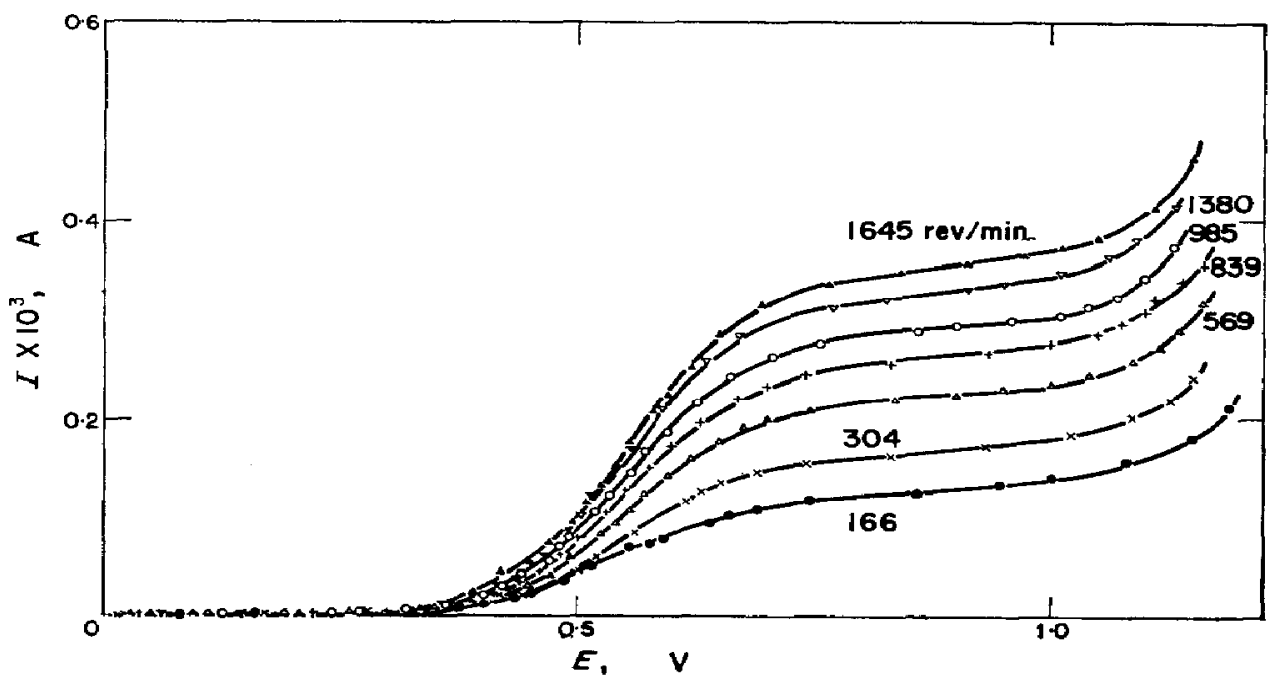

Fig. 1. Current/voltage curves at different rotation speeds. $\mathrm{C}_{0}, 4.26 \times 10^{-3} \mathrm{M} ; 247^{\circ} \mathrm{C}$.

these curves, those corresponding to the solvent melt were also recorded in order to correct the former for the residual current. These curves, as illustrated in Figs. 1-3 after correction for any residual current and pseudo-ohmic drops, the latter being only relevant at the highest currents, are characterized by three clearly defined regions. The first, comprising an overvoltage between 0 and $0.3 \mathrm{~V}$, presents a small current flow. The second, in the range between 0.3 and $0.7 \mathrm{~V}$, presents a steep increase of current. The third, beyond $0.7 \mathrm{~V}$, corresponds to a current plateau. On increasing the potential further, beyond $1 \mathrm{~V}$ for instance, a new electrochemical process sets in, involving the solvent-melt decomposition, and a second steep increase of current is found.

At lower overvoltages the curves change little with the rotation speed of the disk electrode, but at higher overvoltages the current increases with the rotation speed.

The limiting current $I_{L}$ at constant temperature, increases linearly with the square root of the rotation speed $\omega$, as illustrated in Fig. 4. The set of straight lines intercepts the plot at the origin, the slope depending also linearly on concentration of sodium nitrite as shown in Fig. 5. 


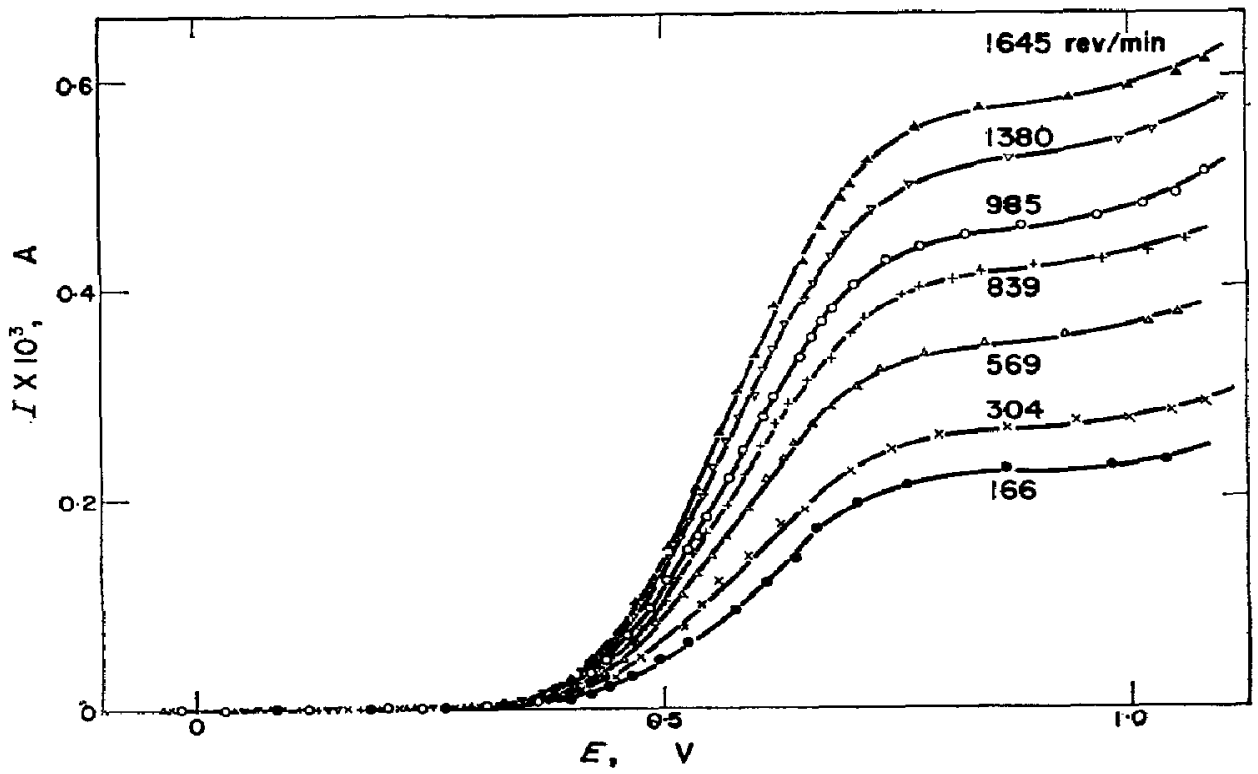

Fig. 2. Current/voltage curves at different rotation speeds. $C_{0}, 7 \cdot 3 \times 10^{-3} \mathrm{M} ; 247^{\circ} \mathrm{C}$.

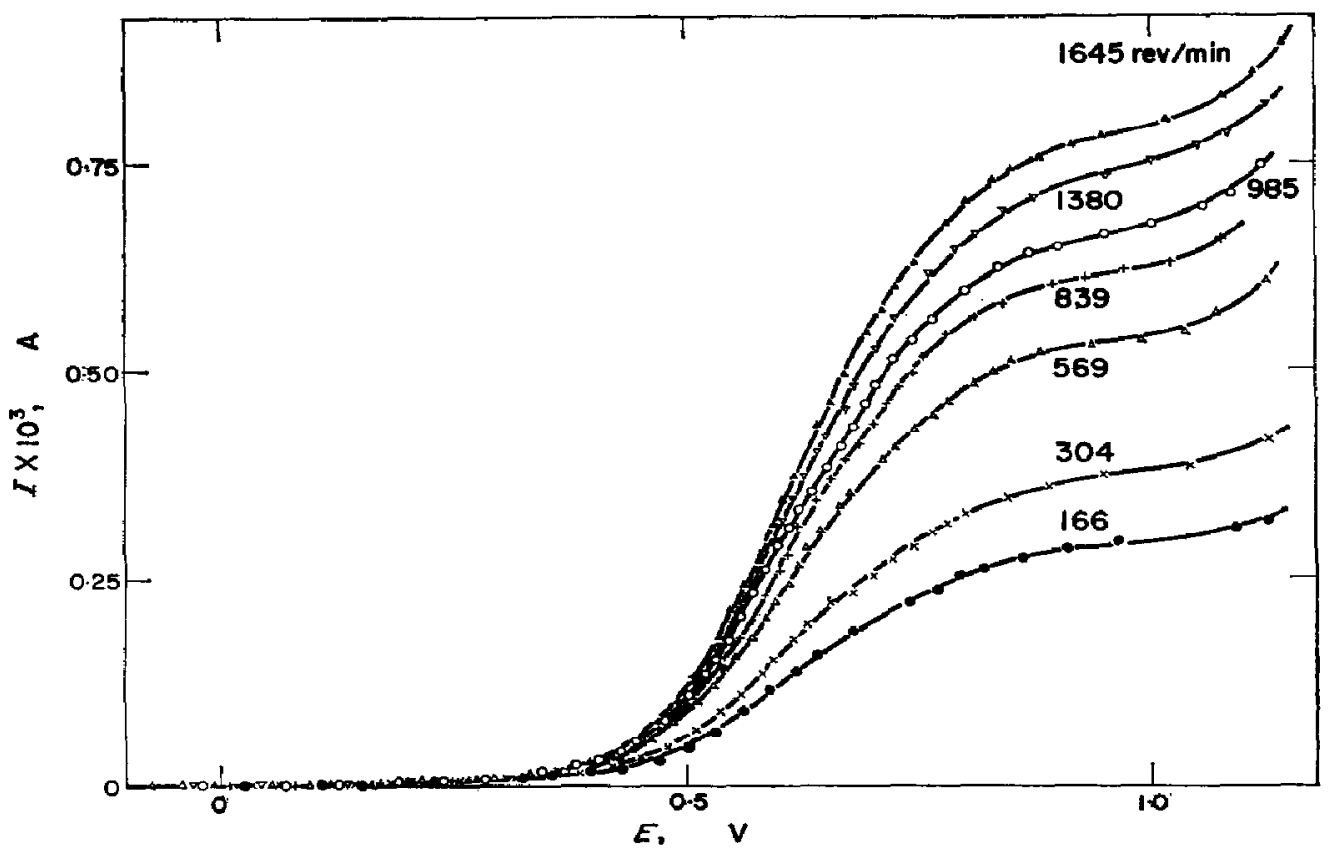

FIG. 3. Current/voltage curves at ditferent rotation speeds. $C_{0}, 7 \cdot 3 \times 10^{-8} \mathrm{M} ; 312^{\circ} \mathrm{C}$. 


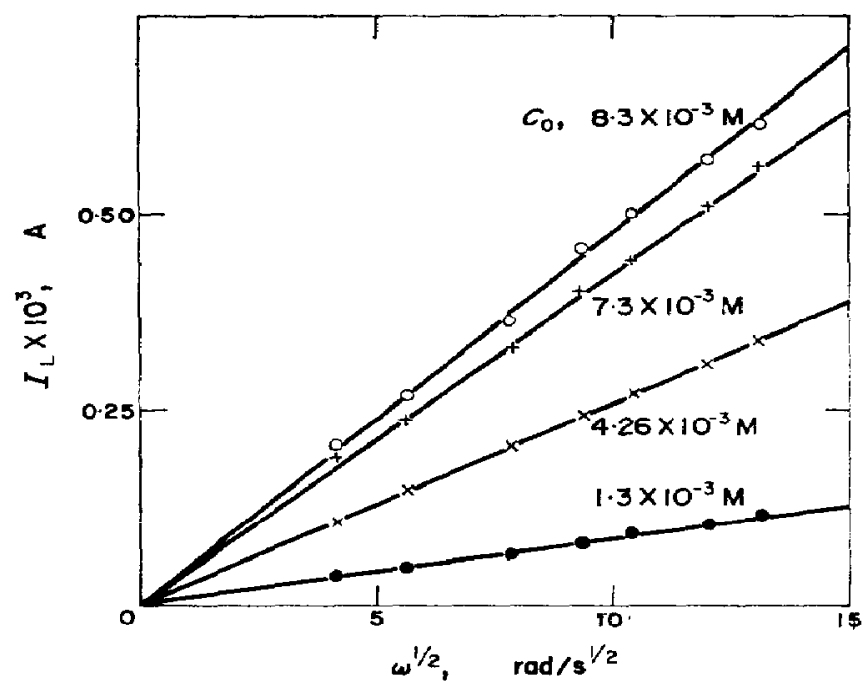

FIG. 4. $I_{\mathrm{L}}$ os $\omega^{1 / 2}$ plot. $C_{0}, 8.3 \times 10^{-3} \mathrm{M}, 247^{\circ} \mathrm{C}$.

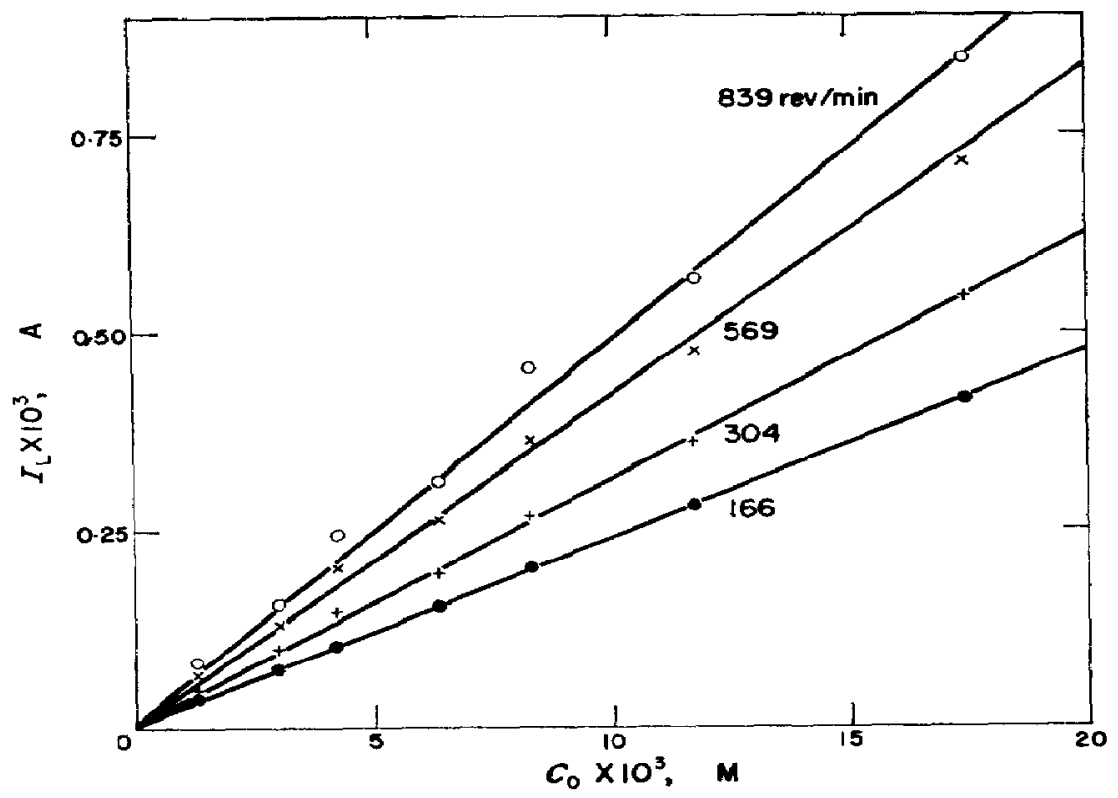

FIG. 5. Dependence of $I_{\mathrm{l}}$ on nitrite concentration at constant rotation speed. $247^{\circ} \mathrm{C}$.

If the $I v s$. $\omega^{1 / 2}$ plot is made at fixed overvoltages lower than $0 \cdot 5 \mathrm{~V}$, a deviation from a straight line is noticed. The lower the overvoltage, the larger the departure. Current/voltage curves also exhibit a distortion at the same limiting current, since as the rotation speed is increased its corresponding overvoltage region becomes narrower. Furthermore, the half-wave potential read from current/voltage curves depends on the rotation speed, as indicated in Table 1. 
Table 1. Half-Waye potentials from current/Yoltage curves

\begin{tabular}{|c|c|c|c|}
\hline \multirow{2}{*}{$\begin{array}{c}247^{\circ} \mathrm{C} \\
\omega \\
\mathrm{rad} / \mathrm{s}\end{array}$} & \multicolumn{3}{|c|}{$\mathrm{Ag} / 0.1 \mathrm{M} \mathrm{Ag}^{+}$(nitrate melt) reference electrode } \\
\hline & $\left(E_{1 / 3}\right)_{o_{0}}-1.3 \times 10^{-8} \mathrm{M}$ & $\left(E_{1 / 2}\right)_{o_{0}-2.28 \times 10^{-8} \mathrm{M}}$ & $\left(E_{1 / 2}\right)_{C_{0}-11.70 \times 10^{-3}} \mathrm{~V}^{\mathrm{N}}$ \\
\hline $17 \cdot 4$ & $0.503 \pm 0.010$ & $0.523 \pm 0.010$ & $0.515 \pm 0.010$ \\
\hline $31 \cdot 8$ & 0.508 & 0.538 & 0.525 \\
\hline $61 \cdot 6$ & 0.513 & 0.533 & $0 \cdot 530$ \\
\hline $87 \cdot 8$ & 0.517 & 0.543 & 0.533 \\
\hline $107 \cdot 7$ & 0.520 & 0.545 & 0.535 \\
\hline $144 \cdot 0$ & 0.530 & 0.548 & $0 \cdot 543$ \\
\hline $172 \cdot 1$ & 0.540 & 0.551 & 0.545 \\
\hline
\end{tabular}

The overvoltage related to a fixed current decreases as temperature increases, as deduced from current/voltage curves. The limiting current fits an Arrhenius plot in the temperature range investigated, as shown in Fig. 6. The average experimental activation energy for the convective-diffusion process, calculated from the slope of the straight line of Fig. 6 , is $3.7 \pm 0.3 \mathrm{Kcal} / \mathrm{mole}$.

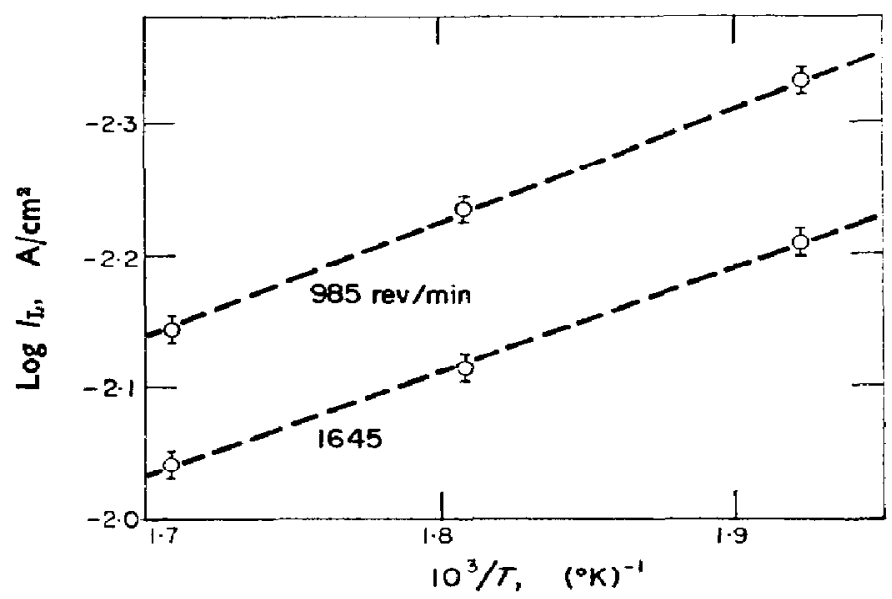

Fig. 6. Dependence of $I$ on temperature: Arrhenius plot. $C_{0}, 7 \cdot 3 \times 10^{-3} \mathrm{M}$

Viscosity of the melts

The viscosity coefficient $\eta$ of the melt was calculated from

$$
\eta=K p t,
$$

where $p$ is the pressure in torr acting upon the electrolyte, $t$ the time required for a constant volume of electrolyte to flow between the two fixed levels of the viscometer and $K$ a constant obtained by calibration of the viscometer with melts of known viscosity coefficients, such as silver nitrate in the temperature range from 281 to $306^{\circ} \mathrm{C}$ and the eutectic $\mathrm{NaNO}_{3}-\mathrm{KNO}_{3}$ in the range from 224.5 to $339^{\circ} \mathrm{C} .{ }^{23,24}$ The constant was $K \times 10^{5}=2.296 \pm 0.050 \mathrm{~g} /$ torr.cm. $\mathrm{s}^{2}$ and, at least within the dispersion of results, and was temperature-independent in the range investigated.

Measurements were carried out over the range of sodium nitrite concentration from $2.7 \times 10^{-3}$ to $29.6 \times 10^{-6} \mathrm{M}$ and temperature from 228 to $334^{\circ} \mathrm{C}$. The product 
pt was kept constant during the experiments. Results are assembled in Table 2.

Table 2. Viscosity of $\mathrm{NaNO}_{2}$ Diluted IN THE EUTECTIC $\mathrm{NaNO}_{3}(45.5 \%) \mathrm{KNO}_{3}(54.5 \%)$

\begin{tabular}{lcc}
\hline $\begin{array}{c}\text { Temp } \\
{ }^{\circ} \mathrm{C}\end{array}$ & $\begin{array}{c}C_{0} \times 10^{3} \\
\mathbf{M}\end{array}$ & $\begin{array}{c}\eta \times 10^{2} \\
\mathrm{~g} / \mathrm{cm} . \mathrm{s}\end{array}$ \\
\hline 334 & 2.7 & 2.461 \\
334 & 13.6 & $2 \cdot 454$ \\
281 & 13.6 & 3.198 \\
262 & 29.6 & 3.588 \\
266 & 29.6 & 3.548 \\
228 & 29.6 & 4.703 \\
\hline
\end{tabular}

No appreciable change of viscosity of the solvent is observed after adding sodium nitrite within the concentration range used in the experiments. The Arrhenius plot of the viscosity coefficient, as shown in Fig. 7, exhibits a slight curvature. However, an average activation energy for viscosity equal to $3.75 \pm 0.30 \mathrm{Kcal} / \mathrm{mole}$ can be calculated.

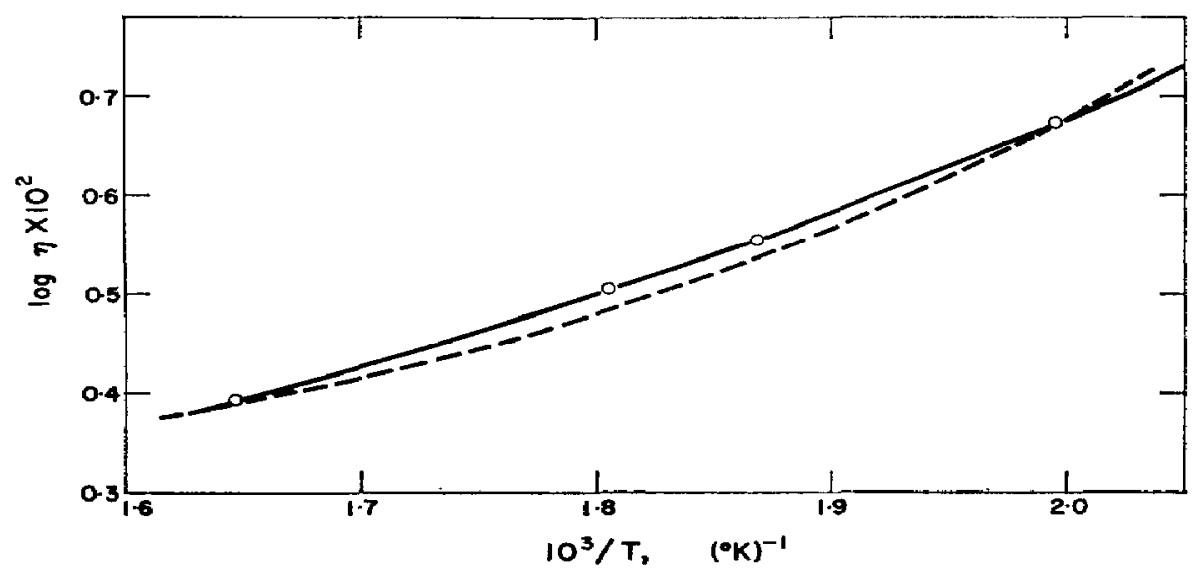

FIG. 7. Arrhenius plot of the viscosity coefficient.

Points correspond to nitrite-nitrate melt. Dotted line refers to nitrate melt.

\section{Diffusion coefficient of nitrite ion}

The limiting current corresponds to a convective-diffusion process, as deduced from its dependence on the rotation speed of the working electrode. Thus, considering the rate equation for a disk electrode as derived by Newman, ${ }^{25,26}$ and the composition of the melt, the diffusion coefficient of the nitrite ion can be evaluated from

$$
\frac{0.62048 z F D^{2 / 3} \nu^{-1 / 6} \omega^{1 / 2} C_{0}}{1+0.2980\left(\frac{D}{\nu}\right)^{1 / 3}+0.14514\left(\frac{D}{\nu}\right)^{2 / 3}},
$$

where $i_{\mathrm{L}}$ is the limiting current density of the convective-diffusion process $\left(\mathrm{A} / \mathrm{cm}^{2}\right)$, $D$, the diffusion coefficient of nitrite ion $\left(\mathrm{cm}^{2} / \mathrm{s}\right), \nu$, the kinematic viscosity $(\nu=\eta / \rho)$ $\left(\mathrm{cm}^{2} / \mathrm{s}\right), \rho$ is the density of the melt, $C_{0}$ is the concentration of nitrite $\left(\mathrm{mole} / \mathrm{cm}^{3}\right)$ in the bulk of the melt and $\omega$, the rotation speed of the disk electrode ( $\mathrm{rad} / \mathrm{s})$. In applying (2), the density of the melt was taken as that of the ionic solvent itself since 
the concentration of nitrite is low and it behaves from the structural viewpoint almost as the nitrate ion. Furthermore, the kinematic viscosity enters (2) with a small fractional exponent making the above approximation satisfactory as regards experimental errors. Values of $D$ at different temperatures are assembled in Table 3.

TABle 3. DIfFusion COEFPICIENT OF NITRITE ION IN NITRATE MELT

\begin{tabular}{|c|c|c|}
\hline$\underset{{ }^{\circ} \mathrm{C}}{\mathrm{Temp}}$ & $\mathrm{C}_{0} \times 10^{3}$ & $\begin{array}{c}D \times 10^{5} \\
\mathrm{~cm}^{2} / \mathrm{s}\end{array}$ \\
\hline 247 & $1 \cdot 30$ & $2.36 \pm 0.12$ \\
\hline 247 & 3.00 & $2.10+0.10$ \\
\hline 247 & $4 \cdot 26$ & $2 \cdot 15 \pm 0.10$ \\
\hline 247 & $6 \cdot 38$ & $1.80 \pm 0.10$ \\
\hline 247 & $7 \cdot 30$ & $1.96 \pm 0.10$ \\
\hline 247 & $8 \cdot 30$ & $\mathbf{1 . 9 7 + 0 . 1 0}$ \\
\hline 247 & $11 \cdot 8$ & $1.72 \pm 0.10$ \\
\hline 247 & $17 \cdot 5$ & $1.65 \pm 0.10$ \\
\hline 280 & $7 \cdot 3$ & $2.67 \pm 0.10$ \\
\hline 312 & $7 \cdot 3$ & $3 \cdot 30 \pm 0.10$ \\
\hline
\end{tabular}

From the temperature dependence of $D$, an experimental activation energy $\Delta E_{D}=$ $4.89 \pm 0.23 \mathrm{Kcal} / \mathrm{mole}$ was obtained. Furthermore, as the kinematic viscosity was also known at various temperatures, the activation energy for viscosity was evaluated as $\Delta E_{p}=3.56 \pm 0.05 \mathrm{Kcal} / \mathrm{mole}$. These figures were employed to calculate the temperature dependence of the limiting cd. Accordingly with (2), we have as a first approximation

$$
i_{\mathrm{L}} \approx \exp \left(-\frac{4 \Delta E_{D}+\Delta E_{v}}{6 R T}\right)=\exp \left(-\frac{3 \cdot 85 \pm 0 \cdot 3}{R T}\right) .
$$

The calculated activation energy from $i_{L}$ is in very good agreement with the experimental result.

Kinetic analysis of current/voltage curves in the region preceding the limiting current.

The overvoltages involved in the current/voltage curves comprise at least two contributions, one due to concentration polarization and another assigned to the activated processes occurring at the electrical double layer. Both contributions are separated according to the case of an intermediate kinetics at the rotating disk electrode, as described in the literature, ${ }^{27}$ on the basis of the Levich equation. ${ }^{28}$

The evidence of intermediate kinetics is determined by the following facts: (i) the magnitude of the limiting current plateau becomes more restricted as the rotation speed of the working electrode is increased; (ii) an appreciable increase of the halfwave potentials on rotation speed is found as shown in the Tables; (iii) no satisfactory linear relationship between cd and $\omega^{1 / 2}$ prevails at a fixed overvoltage much lower than that corresponding to the establishment of the limiting cd. The latter point, however, is not very conclusive as the fixed overvoltage increases, but it is consistent with (i) and (ii).

To determine the order of reaction with respect to nitrite ion, a plot of $\log i$ against $\log \left(1-i / i_{\mathrm{L}}\right)$ was made. ${ }^{29}$ The most likely reaction order was one. Consequently the following expression was used to discriminate between the different 
contributions involved in the joint control,

$$
\frac{1}{i}=\frac{1}{\left(i_{\mathrm{L}}\right)_{\mathrm{K}}}+\frac{1}{A C_{0} \omega^{1 / 2}}
$$

where $i$ is the current density at potential $E,\left(i_{\mathrm{L}}\right)_{\mathrm{K}}$ is a limiting kinetic current, at $1 / \omega^{1 / 2}=0$, corresponding to the electrode process free of any concentration-polarization contribution, and $A$ is $0.62 z F D^{2 / 3} p^{-1 / 6}$. By plotting $1 / i$ against $1 / \omega^{1 / 2}$ at different potentials, a set of straight lines is obtained intersecting the ordinate at $1 /\left(i_{\mathrm{L}}\right)_{\mathrm{K}}$. Typical plots of $1 / i$ vs $1 / \omega^{1 / 2}$ are shown in Fig. 8.

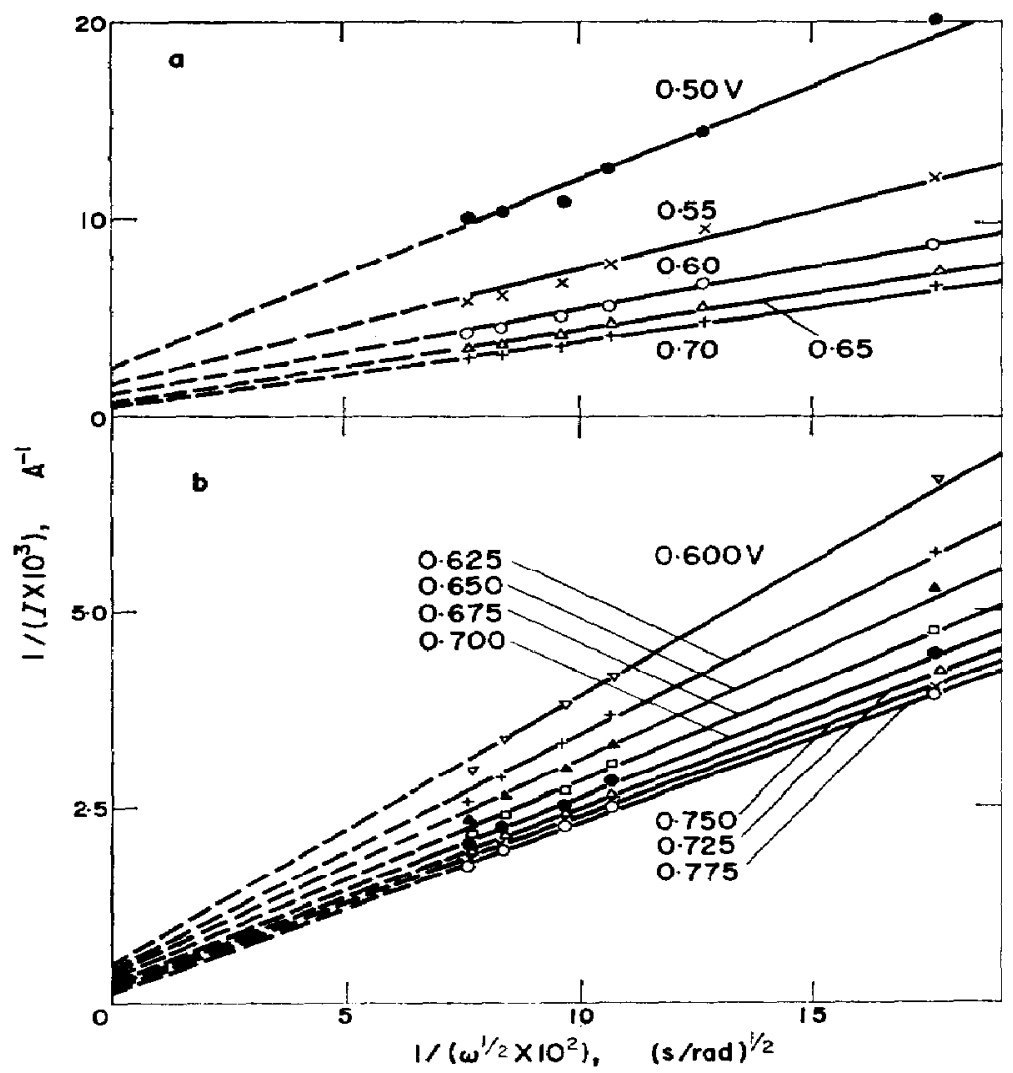

FIG. 8. $1 / I$ os $1 / \omega^{1 / 2}$ plot at different potentials.

$$
\begin{array}{ll}
\text { a: } & C_{0}=4.26 \times 10^{-3} \mathrm{M} ; 247^{\circ} \mathrm{C} \\
\text { b: } \quad C_{0}=7.3 \times 10^{-8} \mathrm{M} ; 247^{\circ} \mathrm{C}
\end{array}
$$

Plots of (4) obtained at potentials larger than $0.5 \mathrm{~V}$ exhibit the slope predicted from the values of the corresponding limiting currents, but this is often not the case at lower voltages. The $\left(i_{L}\right)_{K}$ values were determined at different potentials and plotted according to Tafel equation

$$
E-E_{1}=-\frac{R T}{\alpha_{\mathrm{a}} F} \ln i_{0}+\frac{R T}{\alpha_{\mathrm{a}} F} \ln \left(i_{\mathrm{L}}\right)_{\mathrm{K}},
$$

as shown in Fig. 9. $E_{\mathrm{i}}$ is the initial electrode potential, $\alpha_{\mathrm{a}}$ is the transfer coefficient assisting the anodic reaction in the forward direction, and $i_{0}$ is the apparent exchange cd. The anodic Tafel slope is $b_{T}=2 \cdot 3\left(R T / \alpha_{\mathrm{n}} F\right)$. Values of $b_{\mathrm{T}}$ and $i_{0}$ at various 


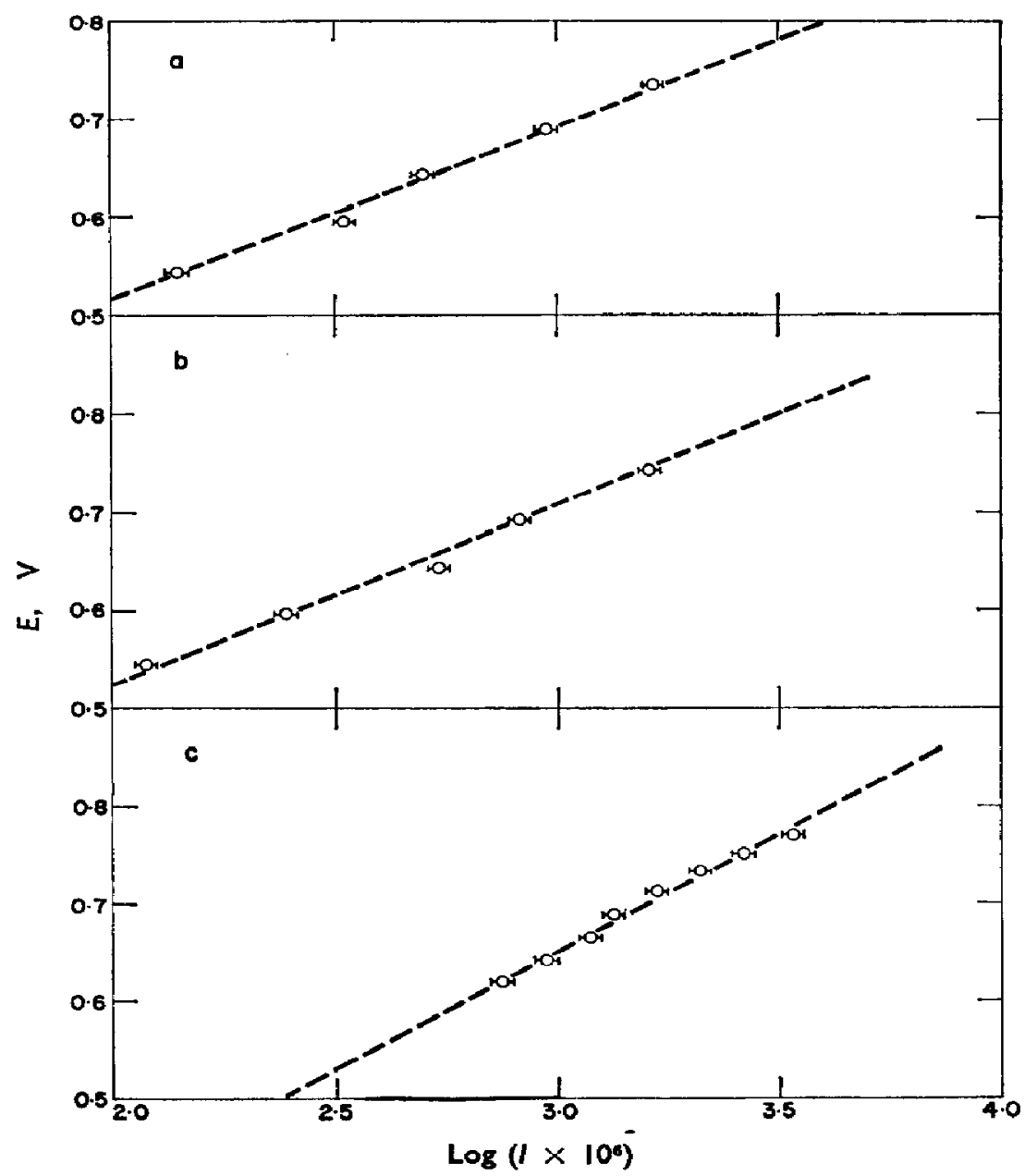

FIG. 9. Potential/log (current) plots of the anodic oxidation of nitrite diluted in nitrate melts.

$$
\begin{array}{ll}
\text { a: } & C_{0}, 1.3 \times 10^{-8} \mathrm{M} ; 247^{\circ} \mathrm{C} \\
\text { b: } & C_{0}, 4.26 \times 10^{-8} \mathrm{M} ; 247^{\circ} \mathrm{C} \\
\text { c: } & C_{0}, 7.3 \times 10^{-3} \mathrm{M} ; 312^{\circ} \mathrm{C}
\end{array}
$$

temperatures and concentrations are assembled in Table 4. The data, in spite of the dispersion, show that $i_{0}$ changes on the average linearly with the nitrite-ion concentration, as illustrated in Fig. 10. It also increases with temperature, although no definite estimation of the activation energy can be made.

\section{DISCUSSION}

Principal reaction and side reactions

The discharge of nitrite ion dissolved in nitrate melts takes place mainly through the one-electron reaction

$$
\mathrm{NO}_{2}{ }^{-} \rightarrow \mathrm{NO}_{2}+\mathrm{e}
$$

as has been previously indicated. This conclusion is immediately deduced from the current/voltage curves. As these curves are mainly determined by the concentration polarization term, if $E$ is plotted against $\log \left(I_{\mathrm{L}}-I\right) / I$, where $I_{\mathrm{L}}$ is the limiting current 
TABle 4. Kinetic Parameters derived from TAFet plots

\begin{tabular}{|c|c|c|c|}
\hline${ }^{\text {Temp }} \mathrm{C}$ & $C_{\mathrm{o}} \times 10^{3}$ & $\begin{array}{c}b \\
V\end{array}$ & $\begin{array}{c}\left(i_{0} \times 10^{5}\right)_{E-0} \\
\mathrm{~A} / \mathrm{cm}^{2}\end{array}$ \\
\hline $\begin{array}{l}247 \\
247 \\
247 \\
247 \\
247 \\
247 \\
247 \\
280 \\
312\end{array}$ & $\begin{array}{c}1 \cdot 30 \\
4 \cdot 26 \\
6 \cdot 38 \\
7 \cdot 30 \\
8 \cdot 30 \\
11 \cdot 8 \\
17 \cdot 5 \\
7 \cdot 30 \\
7 \cdot 30\end{array}$ & $\begin{array}{l}0 \cdot 170 \\
0 \cdot 180 \\
0 \cdot 220 \\
0 \cdot 200 \\
0 \cdot 180 \\
0 \cdot 192 \\
0 \cdot 220 \\
0 \cdot 220 \\
0.240\end{array}$ & $\begin{array}{l}0.10-0.40 \\
0.18-0.65 \\
0.80-1 \cdot 6 \\
0.56-1 \cdot 8 \\
0.43-1 \cdot 4 \\
0.56-1 \cdot 3 \\
1 \cdot 3-2 \cdot 4 \\
1.4-2 \cdot 5 \\
2 \cdot 3-2 \cdot 8\end{array}$ \\
\hline
\end{tabular}

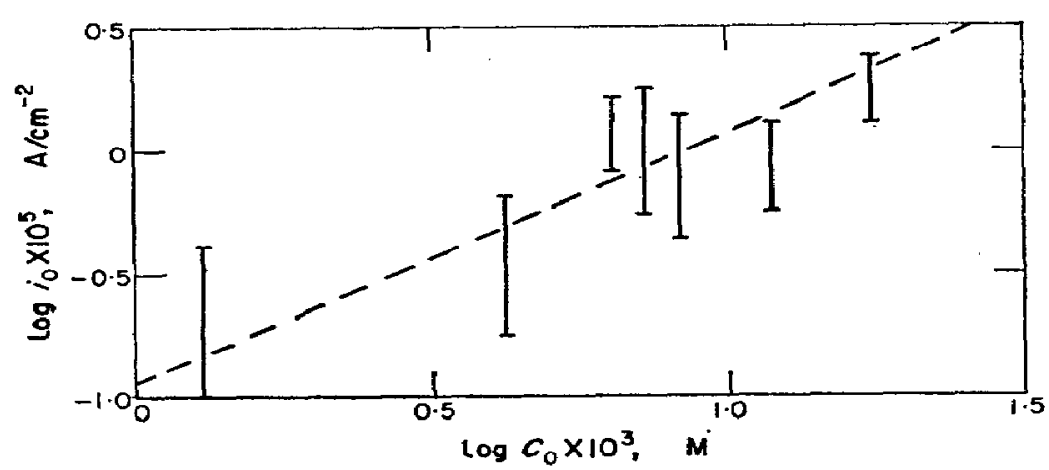

Fig. 10. Concentration dependence of the exchange cd. Dotted line has unit slope. $247^{\circ} \mathrm{C}$.

of the anodic process, a straight line results approaching a slope larger than $2 \cdot 3 R T / F$, as shown in Fig. 11. If these results are interpreted in terms of the one-electron process according to (6), as already indicated by different authors, then the appreciable deviation from the reversible conditions is due to a significant contribution of activation polarization. On the other hand, if the main reaction were

$$
2 \mathrm{NO}_{2}-\rightarrow \mathrm{NO}_{3}^{-}+\mathrm{NO}+\mathrm{e},
$$

as concluded from the determination of the decomposition potential of alkali nitrites, ${ }^{27}$ the Nernst equation would involve one electron per two nitrite ions, which is not observed in the present circumstances.

The study of the thermal decomposition of molten nitrates and nitrites ${ }^{17,18}$ has yielded information about the occurrence of the following reaction deduced from the acid-base properties of the melt,

$$
\mathrm{NO}_{2}^{-}+\mathrm{NO}_{2} \rightarrow \mathrm{NO}_{3}^{-}+\mathrm{NO} \text {. }
$$

If the reaction between nitrogen dioxide and molten nitrite interferes appreciably in the electrode process, a net decrease of nitrite-ion concentration should be observed and an equivalent amount of NO should be produced. Consequently the nitrite wave should decrease after repeated runs. This effect however was not particularly noteworthy during the course of the present work. Therefore, although the contribution of (8) should not be disregarded, it has a secondary importance as compared to (6). 


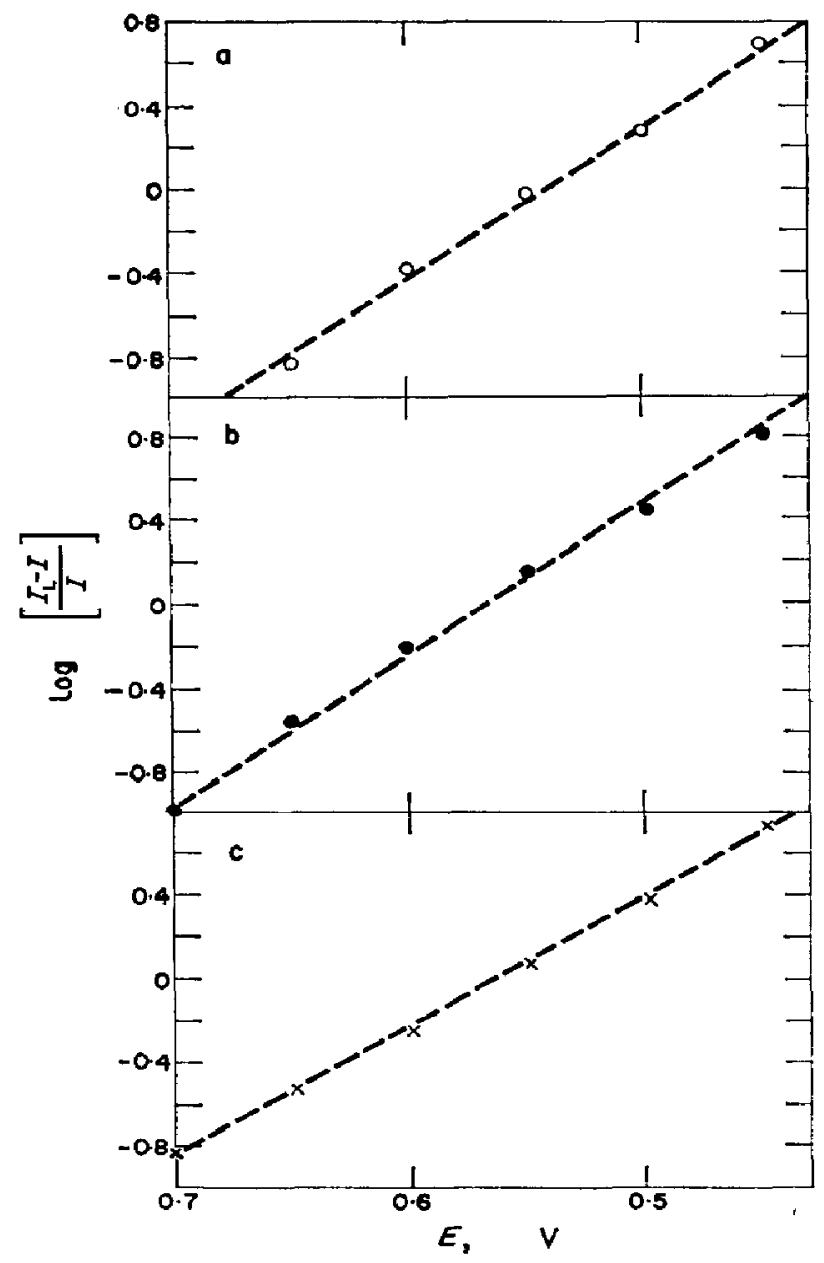

Frc. 11. Current/voltage curves in terms of a concentration polarization equation.

a: $C_{0}, 4-26 \times 10^{-3} \mathrm{M} ; 247^{\circ} \mathrm{C} ; 569 \mathrm{rev} / \mathrm{min}$

b: $C_{0,7.3} \times 10^{-8} \mathrm{M} ; 247^{\circ} \mathrm{C} ; 569 \mathrm{rev} / \mathrm{min}$

c: $C_{0}, 8.3 \times 10^{-8} \mathrm{M} ; 247^{\circ} \mathrm{C} ; 569 \mathrm{rev} / \mathrm{min}$

The slopes of the straight lines lie between $0 \cdot 14$ and $0.16 \mathrm{~V}$.

\section{Mechanism of the anodic reaction}

Before considering the mechanism of the electrode reaction itself a preliminary consideration of the state of the platinum electrode surface must be attempted. There are at present various arguments supporting the idea that platinum electrodes, acting particularly as anodes, are actually oxidized metal surfaces. Moreover, studies both in aqueous ${ }^{31,32}$ as well as in molten systems ${ }^{33}$ have shown that even at a small positive overvoltage platinum is covered with a monolayer of oxide, its probable composition approaching $\mathrm{Pt}(\mathrm{O})$. These conclusions are relevant to the kinetics of the electrode process, in so far as the reaction path and its energetics will depend on the surface state of the metal.

Let us start with the simplest scheme of reaction, assuming the discharge of a nitrite ion on an oxidized platinum electrode site, yielding an adsorbed intermediate 
that in a second act forms nitrogen dioxide, leaving the electrode site free, as follows:

$$
\text { (I) } \begin{cases}\mathrm{NO}_{2}^{-}+\mathrm{Pt}(\mathrm{O}) & \rightarrow \mathrm{Pt}\left(\mathrm{ONO}_{2}\right)+\mathrm{e}, \\ \mathrm{Pt}\left(\mathrm{ONO}_{2}\right) & \rightarrow \mathrm{Pt}(\mathrm{O})+\mathrm{NO}_{2} .\end{cases}
$$

If the surface concentration of the adsorbed intermediate is large, a bimolecular desorption step might occur,

$$
\begin{gathered}
2 \mathrm{Pt}\left(\mathrm{ONO}_{2}\right) \rightarrow 2 \mathrm{Pt}(\mathrm{O})+\mathrm{N}_{2} \mathrm{O}_{4}, \\
\mathrm{~N}_{2} \mathrm{O}_{4} \rightarrow 2 \mathrm{NO}_{2} .
\end{gathered}
$$

This reaction scheme is formally analogous to that earlier presented for nitrite-ion oxidation from the pure melt ${ }^{5}$ with platinum electrodes, except that no particular consideration of the oxidized electrode surface was then postulated. For reasons to be discussed further on, let us consider only scheme (I), where from the kinetic point of view, either (9) or (10) can be rate-determining.

If (9) is rate-determining, at overvoltages larger than $R T / \beta F$ the rate equation becomes

$$
\vec{v}=\vec{k}_{1} a_{1} a_{\mathrm{S}} \exp (z \beta F \eta / R T),
$$

where $\vec{v}$ is the rate of the reaction, $\vec{k}_{1}$ the specific rate constant, and $a_{i}$ and $a_{S}$ are respectively the activity of the reacting species $i$ at the interface and the surface activity; $\eta$ is the overvoltage referred to a reversible nitrite electrode placed in the melt.

The expression of the rate equation at overvoltages larger than $R T / \beta F \mathrm{~V}$ in terms of concentration $C_{0}$, degree of surface coverage by the reaction intermediate $x$, and $\mathrm{cd} i_{a}$, when $x \ll 1$, and the symmetry factor is $0 \cdot 5$, is

$$
i_{\mathrm{a}}=z F k_{1}{ }^{\prime} C_{0} \exp (F \eta / 2 R T),
$$

where $k_{1}{ }^{\prime}$ is now a formal rate constant. Equation (14) gives a Tafel line with a slope equal to $2 R T / F$, as has been determined, and involves a low, potential-independent degree of surface coverage.

As far as the Tafel slope is concerned, other possible rate-determining steps comprised in reaction scheme (I) are not supported by the experimental results.

Another possible reaction scheme can be established providing for the participation of nitronium ion $\left(\mathrm{NO}_{2}{ }^{+}\right)$in the rate process, thus,

$$
\left\{\begin{array}{l}
\mathrm{NO}_{2}^{-}+\mathrm{Pt}(\mathrm{O}) \rightarrow \mathrm{Pt}(\mathrm{O})\left(\mathrm{NO}_{2}\right)+\mathrm{e}, \\
\mathrm{Pt}(\mathrm{O})\left(\mathrm{NO}_{2}\right) \rightarrow \mathrm{NO}_{2}^{+}+\mathrm{Pt}(\mathrm{O})+\mathrm{e}, \\
\mathrm{NO}_{2}{ }^{+}+\mathrm{NO}_{2}^{-} \rightarrow \mathrm{N}_{2} \mathrm{O}_{4} \rightarrow 2 \mathrm{NO}_{2} .
\end{array}\right.
$$

The reaction path initiates with the discharge of a nitrite ion as in scheme (I), but the intermediate now yields the nitronium ion, which finally reacts with nitrite ion to form nitrogen dioxide. Obviously, under the simple conditions already described in discussing scheme (I), if the first reaction is controlling under the proper conditions, a rate equation equivalent to (14) is finally obtained. So if this is the actual ratedetermining step, the foregoing steps entering the reaction mechanism are indistinguishable.

In principle, however, the situation is not so unambiguously defined because, when (16) is rate-determining, a Tafel line with the slope $2 R T / F$ emerges at high overvoltages, with a high degree of surface coverage by the reaction intermediate. 
Therefore scheme (II) with (16) as rate-determing may appear also a likely reaction path. The main difficulty, however, in accepting this reaction mechanism is the failure to detect the existence of the nitronium ion in electrode processes occurring in nitrite and nitrate melts. Hence, the electrode reaction related to the oxidation of nitrite ion in a nitrate melt on platinum is better interpreted in terms of scheme (I), involving (9) as rate-determining step.

Although the postulated mechanism is reasonable for the main reaction, further participation of additional processes should be considered particularly as to its influence on the electrode reaction. Thus, the formation of nitric oxide may occur after the initial discharge of the nitrite ion, according to

$$
\mathrm{Pt}(\mathrm{O})\left(\mathrm{NO}_{2}\right)+\mathrm{NO}_{2}^{-} \rightarrow \mathrm{NO}_{3}{ }^{-}+\mathrm{NO}+\mathrm{Pt}(\mathrm{O}) \text {. }
$$

Reaction (18), which follows the rate-determining step and involves a minor yield, apparently has no significant influence on the kinetics of the electrode reaction.

Another reaction that may interfere at very high anodic overvoltages is the oxidation of platinum, which can occur according to

$$
\mathrm{Pt}(\mathrm{O})\left(\mathrm{NO}_{2}\right) \rightarrow \mathrm{NO}_{3}-+\mathrm{Pt}^{2+}+\text { e. }
$$

This reaction is probably responsible for the dissappearence of the electrode metallic brightness, which was actually observed at overvoltages beyond those where the limiting cd for nitrite ion oxidation was established.

In spite of the uncertainty involved in the exchange, cd values, they increase as the nitrite-ion concentration increases and the reaction order with respect to nitrite ion is close to 1 . This result fits into the mechanistic interpretation given to the electrode process in the absence of complex double-layer effects.

Anodic nitrite-ion oxidation with pure melts and with melts diluted in nitrate

A different reaction mechanism seems to apply to the nitrite-ion oxidation when nitrite is diluted in nitrate melts from the one earlier postulated for the pure molten alkali nitrites, presenting an apparent contradiction. For the latter the Tafel slope on platinum was $R T / F$ at overvoltages lower than those reported in the present work but at higher overvoltages it was $R T / 2 F$. The proposed mechanism, without considering (19) and (20) but assuming the oxidation of the platinum surface, is

$$
\begin{aligned}
\mathrm{NO}_{2}-+\mathrm{Pt}(\mathrm{O}) & \rightarrow \mathrm{Pt}(\mathrm{O})\left(\mathrm{NO}_{2}\right)+\mathrm{e}, \\
\mathrm{Pt}(\mathrm{O})\left(\mathrm{NO}_{2}\right) & \rightarrow \mathrm{NO}_{2}+\mathrm{Pt}(\mathrm{O}),
\end{aligned}
$$

or

$$
\begin{aligned}
2 \mathrm{Pt}(\mathrm{O})\left(\mathrm{NO}_{2}\right) & \rightarrow\left(\mathrm{N}_{2} \mathrm{O}_{4}\right)+2 \mathrm{Pt}(\mathrm{O}), \\
\left(\mathrm{N}_{2} \mathrm{O}_{4}\right) & \rightleftarrows 2 \mathrm{NO}_{2}, \\
\mathrm{NO}_{2} & \rightleftarrows \mathrm{NO}+\frac{1}{2} \mathrm{O}_{2} .
\end{aligned}
$$

Reaction (22) is rate-determining at low overvoltages while (23) becomes rate-determining at high overvoltages. This interpretation is acceptable for the pure melt but no longer holds for the dilute nitrite, as far as the rate-determining step is concerned. Thus, (21) depends on nitrite-ion concentration, as shown in (15), and under a consecutive scheme of reaction, it is reasonable that in the dilute region the rate of the electron-transfer step becomes rate-determining. Furthermore, the rate of step (21) increases more slowly with the overvoltage than those of (22) and (23), as deduced 
from the corresponding rate equations, which makes (21) a more likely rate-determining step in dilute solutions.

Consequently, the mechanism postulated for the anodic oxidation of nitrite ion on platinum in dilute nitrate solutions is comprised in that postulated for the pure nitrite melts, the change from one to the other being due to the lower concentration of the reacting species.

The mechanism for the dilute melt suggests that a reversible nitrite electrode in this case is not quite reliable-because the electron-transfer process should be considered as a rather sluggish process.

Another interesting fact is that the intermediate species formed in the anodic oxidation of nitrite ion, assuming an oxidized platinum surface, is equivalent to the intermediate species already postulated for the nitrate-ion oxidation on platinum, which involves a bond formation between the metal and one oxygen atom. ${ }^{36}$

The electrochemical kinetic behaviour of dilute molten nitrites on platinum fits into the general kinetic picture deduced for the pure salt and for molten nitrates.

Acknowledgements-This work was in part supported with funds granted by the Consejo Nacional de Investigaciones Cientificas y Técnicas of Argentina. M.E.M. thanks the Consejo for the fellowship granted.

\section{REFERENCES}

1. YU. S. Lyalikov and R. M. Novik, Uchen. Zap. Kish. Univ. 26, 61 (1957)

2. R. M. NoviK and YU. S. LYALIKOV, Zh. anal. Khim. 13, 691 (1958).

3. H. S. SWOfFord and P. G. MC CoRmiCK, Analyt. Chem. 37, 970 (1965)

4. G. G. Bombi, R. Freddi and M. Fiorani, Annali Chim, 56, 759 (1966).

5. A. J. Caldandra and A. J. Arvía, Electrochim. Acta 11, 1173 (1966).

6. A. J. Arvía and A. J. Calandra, Electrochim. Acta 12, 1441 (1967).

7. B. J. Brough and P. H. KerRIDGe, Inorg. Chem. 4, 1353 (1965).

8. F. R. DukE, J. chem. Ed. 39, 57 (1962).

9. H. Lux, $Z$. anorg. allg. Chem. 250, 259 (1942).

10. H. Lux, $Z$. anorg. allg. Chem. 257, 79 (1948).

11. H. Lux, Z. elektrochem. 52, 224 (1948).

12. H. Lux, $Z$. elektrochem. 53, 43 (1949).

13. B. Tremillon, Revue Chim. minér. 3, 767 (1966).

14. A. M. Shams El Din and A. A. A. Gerges, Electrochim. Acta 9, 613 (1964).

15. M. Francini, J. electrochem. Soc. 111, 81-c (1965).

16. D. Inman and J. Braunstein, Coll. Czech. Chem. Commun. 148 (1966).

17. F. VRatny and F. Gugliotta, J. inorg. nucl. Chem. 20, 252 (1961).

18. T. M. OzA, J. Am. chem. Soc. 78, 3564 (1956).

19. L. E. Topol, R. A. Osteryoung and J. H. Christie, J. phys. Chem. 70, 2857 (1966).

20. A. J. Calandra and A. J. Arvía, Electrochim. Acta 12, 95 (1967).

21. A. J. Arví, S. L. Marchiano and J. J. PodestA, Electrochim. Acta 12, 259 (1967).

22. H. Bloom, B. S. Harrap and E. Heymann, Proc. $R$. Soc. A194, 237 (1948).

23. F. A. Pugsley and F. E. W. Wetmore, Can. J. Chem. 32, 839 (1954).

24. V. C. Reinsborough, Aust. J. Chem. 20, 1037 (1967).

25. J. NewMan, $J$. phys. Chem. 70, 1327 (1966).

26. J. NeWMAN, in Advances in Electrochemistry and Electrochemical Engineering, ed. P. DELAHAY and C. W. Tobias, Vol. 5, p. 87. Interscience, New York (1967).

27. A. Frumkin and G. Tedoradse, $Z$. Elektrochem. 62, 251 (1958).

28. V. G. Levich, Physicochemical Hydrodynamics. Prentice-Hall, Englewood Cliffs, New Jersey (1962).

29. A. C. RIDDIFORD, in Advances in Electrochemistry and Electrochemical Engineering, ed. P. Delahay and C. W. Tomias, Vol. 4, p. 96. Interscience, New York (1966).

30. P. I. Protsenko and A. V. Protsenko, Ukr. khim. 30, 1051 (1964).

31. A. Damuanovic, A. Dey and J. O'M. Bockris, Electrochim. Acta 11, 791 (1966).

32. S. Schuldiner and T. B. WARNER, J. electrochem. Soc. 112, 212 (1965).

33. A. J. Arvfa, A. J. Calandra and H. A. Videla, Electrochim. Acta 13, 167 (1968).

34. W. E. TriacA and A. J. Arvia, Electrochim. Acta 10, 409 (1965). 